\title{
The Ceramic Waste Form Process at the Idaho National Laboratory
}

\section{International Pyroprocessing Research Conference}

Stephen Priebe Ken Bateman

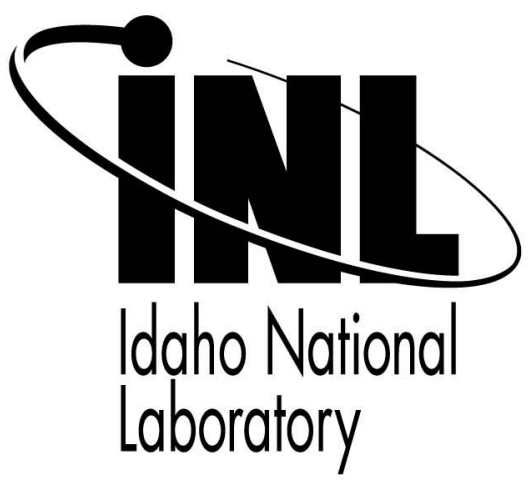

This is a preprint of a paper intended for publication in a journal or proceedings. Since changes may be made before publication, this preprint should not be cited or reproduced without permission of the author. This document was prepared as an account of work sponsored by an agency of the United States Government. Neither the United States Government nor any agency thereof, or any of their employees, makes any warranty, expressed or implied, or assumes any legal liability or responsibility for any third party's use, or the results of such use, of any information, apparatus, product or process disclosed in this report, or represents that its use by such third party would not infringe privately owned rights. The views expressed in this paper are not necessarily those of the United States Government or the sponsoring agency. 


\title{
The Ceramic Waste Form Process at the Idaho National Laboratory ${ }^{1}$
}

\author{
Stephen Priebe and Ken Bateman \\ Idaho National Laboratory \\ P.O. Box 1625 \\ Idaho Falls, ID
}

\section{Introduction}

Spent sodium-bonded metallic nuclear fuel from the Experimental Breeder Reactor II (EBR II) is treated by electrometallurgical techniques (Ref. 1, 2). Relatively pure uranium is separated from the rest of the fuel by electrotransport at $450^{\circ} \mathrm{C}$ to $500^{\circ} \mathrm{C}$. The spent fuel is chopped and placed into a batch of LiCl- $\mathrm{KCl}$ eutectic salt that contains 2 mol\% actinide chlorides. Current is passed between the fuel (anode) and a steel mandrel (cathode). As the fuel is oxidized, metal chlorides form in the salt and uranium chloride is reduced to metal at the cathode. Chemically noble fission products, fuel matrix materials, and cladding hulls are removed from the salt and processed into a metal waste form. Reactive metal fuel constituents, including all the TRU metals and the majority of the fission products remain in the salt as chlorides and are processed into a ceramic waste form (CWF). The TRU and fission products build up in the salt bath until one of the following conditions is met:

- Sodium concentration - sodium increases the melting point of the salt. The most recent electrorefiner test show that a maximum of about 23 weight percent sodium can be tolerated.

- Plutonium quantity/concentration - the plutonium is associated with criticality. For transuranic recovery, the ratio of $\mathrm{PuCl}_{3}$ to $\mathrm{UCl}_{3}$ needs to be above 3 to 1 .

- Decay heat content of fission products - the decay heat content of the fission products impacts subsequent processing and storage of the ceramic waste form.

- Salt level - as fuel is processed, and $\mathrm{UCl}_{3}$ or $\mathrm{CdCl}_{2}$ is added, the salt level will rise in the electrorefiner. If none of the three above limits is reached, salt may have to be removed to maintain an acceptable level.

For processing EBR II fuel, the limiting factor is considered to be the sodium chloride concentration, with a maximum being about $23 \%$ sodium. Once the sodium limit is reached, salt is replaced at a rate to maintain the sodium concentrations below this limit. The removed salt is solidified and transferred to the CWF process.

Salt is ground to a particle-size range of $45 \mu$ to $250 \mu$ and mixed with dried Zeolite $4 \mathrm{~A}$ that has been ground to the same particle-size range. The salt and zeolite are mixed and heated to $500^{\circ} \mathrm{C}$ for about 18 hours. During this process, the salt occludes into the structure of the zeolite. The salt-loaded zeolite (SLZ) is cooled and then mixed with borosilicate glass frit with a comparable particle-size range. The SLZ/glass mixture is

\footnotetext{
${ }^{1}$ Acknowledgement - Work supported by the U.S. Department of Energy, Office of Nuclear Energy, under DOE Idaho Operations Office Contract No. DE-AC07-05ID14517.
} 
transferred to a crucible, which is heated to $925^{\circ} \mathrm{C}$. The zeolite is converted to the final sodalite form and the glass thoroughly encapsulates the sodalite, producing a dense, leach-resistant final waste form.

Initial development of the CWF took place at Argonne National Laboratory East. Process scale up and demonstration up to about $140 \mathrm{~kg}$ was conducted at Argonne National Laboratory - West, now the Materials and Fuels Complex (MFC) at Idaho National Laboratory (INL). This paper describes the current status of development for the CWF process and the plans for final scale up for treatment of EBR-II spent fuel.

\section{CWF Process}

\section{Input Materials}

Salt - The electrorefiner salt that becomes the feed for the CWF depends upon the type of fuel processed and the conditions under which salt is removed from the electrorefiner. Electrochemical processing of the spent fuel leads to the transuranics and alkali, alkaline earth, rare earth, and halide fission products being in the salt phase. Sodium in the fuel is also oxidized in the salt. A certain level of actinide chlorides (primarily $\mathrm{UCl}_{3}$ and/or $\mathrm{PuCl}_{3}$ ) is maintained in the salt to facilitate desirable electrotransport conditions. However, as reactive metal fission products and sodium dissolve into the salt, they are preferentially oxidized, which reduces the actinide chlorides. To maintain the actinide chloride concentration, $\mathrm{UCl}_{3}$ and/or $\mathrm{CdCl}_{2}$ are periodically added to the salt. The current composition of the salt removed from the electrorefiners is shown in Table 1. The data shown in this table represents the salt composition when $100 \%$ of the EBR II driver assemblies and 100\% of the EBR II blanket assemblies have been processed. As can be seen even when all of the drivers have been processed, the sodium limit has not been reached.

Table 1. Salt composition resulting from processing EBR II driver and blanket fuel.

\begin{tabular}{lrrrr} 
& \multicolumn{2}{c}{ EBR II Drivers } & \multicolumn{2}{c}{ EBR II Blankets } \\
& $\begin{array}{c}\text { Wt \% of } \\
\text { chloride salt }\end{array}$ & $\begin{array}{c}\text { Mole \% of } \\
\text { chloride salt }\end{array}$ & $\begin{array}{c}\text { Wt \% of } \\
\text { chloride salt }\end{array}$ & $\begin{array}{c}\text { Mole \% of } \\
\text { chloride salt }\end{array}$ \\
$\mathrm{LiCl} / \mathrm{KCl}$ & $69.14 \%$ & $81.53 \%$ & $47.10 \%$ & $63.20 \%$ \\
$\mathrm{NaCl}$ & $12.16 \%$ & $13.71 \%$ & $23.66 \%$ & $30.34 \%$ \\
$\mathrm{RbCl}$ & $0.23 \%$ & $0.12 \%$ & $0.01 \%$ & $0.01 \%$ \\
$\mathrm{SrCl}_{2}$ & $0.65 \%$ & $0.27 \%$ & $0.03 \%$ & $0.01 \%$ \\
$\mathrm{YCl}_{3}$ & $0.47 \%$ & $0.16 \%$ & $0.03 \%$ & $0.01 \%$ \\
$\mathrm{CsCl}$ & $1.66 \%$ & $0.64 \%$ & $0.15 \%$ & $0.07 \%$ \\
$\mathrm{BaCl}_{2}$ & $0.86 \%$ & $0.27 \%$ & $0.11 \%$ & $0.04 \%$ \\
$\mathrm{LaCl}_{3}$ & $0.82 \%$ & $0.22 \%$ & $0.08 \%$ & $0.02 \%$ \\
$\mathrm{CeCl}_{3}$ & $1.55 \%$ & $0.41 \%$ & $0.15 \%$ & $0.04 \%$ \\
$\mathrm{PrCl}_{3}$ & $0.77 \%$ & $0.21 \%$ & $0.07 \%$ & $0.02 \%$ \\
$\mathrm{NdCl}_{3}$ & $2.63 \%$ & $0.69 \%$ & $0.24 \%$ & $0.07 \%$ \\
$\mathrm{PmCl}_{3}$ & $0.03 \%$ & $0.01 \%$ & $0.00 \%$ & $0.00 \%$ \\
$\mathrm{SmCl}_{3}$ & $0.50 \%$ & $0.13 \%$ & $0.07 \%$ & $0.02 \%$
\end{tabular}




$\begin{array}{llrrr}\mathrm{EuCl}_{3} & 0.03 \% & 0.01 \% & 0.01 \% & 0.00 \% \\ \mathrm{NpCl}_{3} & 0.08 \% & 0.02 \% & 0.02 \% & 0.00 \% \\ \mathrm{UCl}_{3} & 5.81 \% & 1.12 \% & 9.21 \% & 2.01 \% \\ \mathrm{PuCl}_{3} & 2.51 \% & 0.49 \% & 19.05 \% & 4.11 \%\end{array}$

Salt, as received from the electrorefiners, is in truncated cones approximately 5 $\mathrm{cm}$ by $5 \mathrm{~cm}$, which must be crushed and ground to a particle size range of $45 \mu \mathrm{m}$ to $250 \mu \mathrm{m}$. Radioactive salt is crushed in a VD Chipmunk jaw crusher installed in a dry argon atmosphere hot cell. It is then ground in a Prater mill/classifier and stored under argon.

To facilitate development work and reduce costs, two types of surrogate salts are used. The first type is a simple $\mathrm{LiCl} / \mathrm{KCl}$ eutectic salt. This salt has been used in numerous small-scale tests of salt-zeolite occlusion and glass testing. A more representative surrogate salt contains non-radioactive isotopes, at the same concentrations as in the above salts, with the exception of $\mathrm{UCl}_{3}$ and $\mathrm{PuCl}_{3}$. This surrogate salt yields good representative data without the need for containment or other provisions required for working with radioactive materials.

Surrogate salt is sized in an argon glovebox using a Sepor Inc. jaw crusher to crush large chunks of salt into fragments of about $0.5-\mathrm{cm}$ diameter for feeding into a Mazzer mini electronic coffee grinder. Typical salt particle size distribution is given in Figure 1.

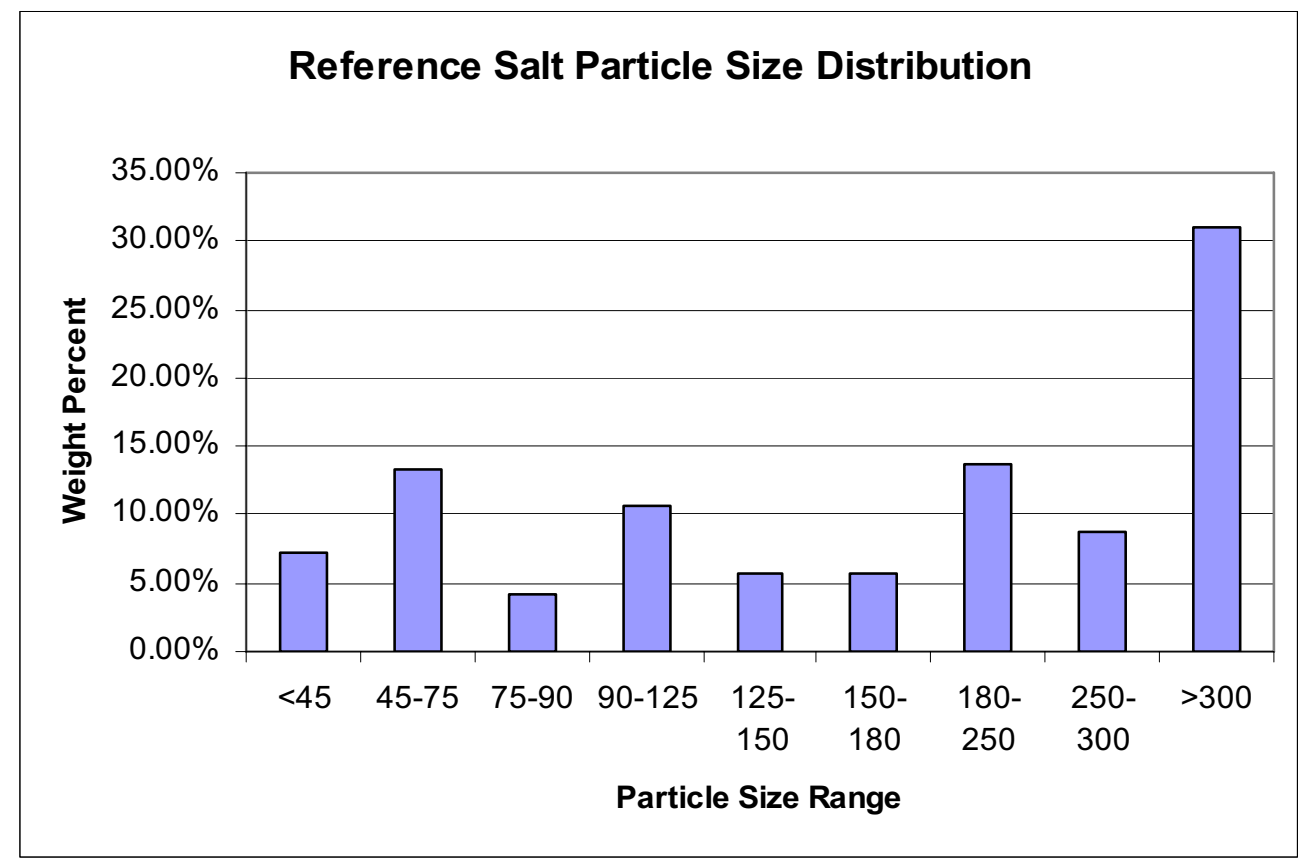

Figure 1. Reference particle size distribution for salt.

Zeolite 4A - Zeolites are crystalline aluminosilicate materials that have a high capacity for adsorption of various molecular species. Their structures are formed from the cross-linking of $\mathrm{SiO}_{2}$ and $\mathrm{AlO}_{2}$ tetrahedra. For the ceramic waste process, zeolite $4 \mathrm{~A}$ 
is used for adsorbing waste salt. The composition of zeolite- $4 \mathrm{~A}$ is $\mathrm{Na}_{12}\left(\mathrm{SiO}_{2}\right)_{12}\left(\mathrm{AlO}_{2}\right)_{12} \bullet \times \mathrm{H}_{2} \mathrm{O}$, as shown in Figure 1.

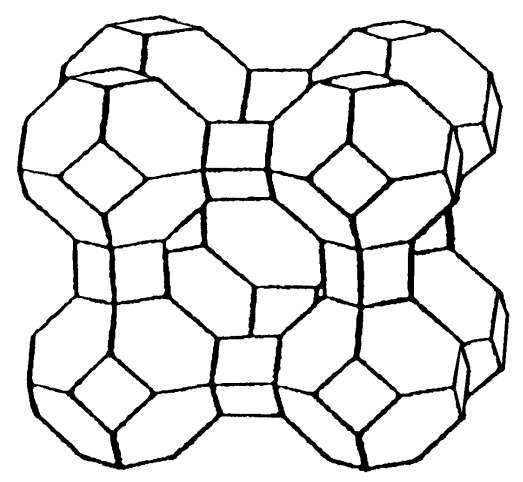

Figure 2. The Zeolite-4A $\alpha$-Cage.

Zeolite 4A is received from UOP as beads with a particle size of about $1.5 \mathrm{~mm}$. To improve salt occlusion and mixing, the zeolite is ground in a roller mill. Early development work used fine powders $(<10 \mu \mathrm{m})$ to improve salt occlusion. However, it was recognized that such fine powders can be difficult to handle, so a larger particle size was tested. Too large a particle size would cause problems mixing with the salt and glass. Therefore as a compromise, a particle size range of $45 \mu \mathrm{m}$ to $250 \mu \mathrm{m}$ was selected as shown in Figure 3.

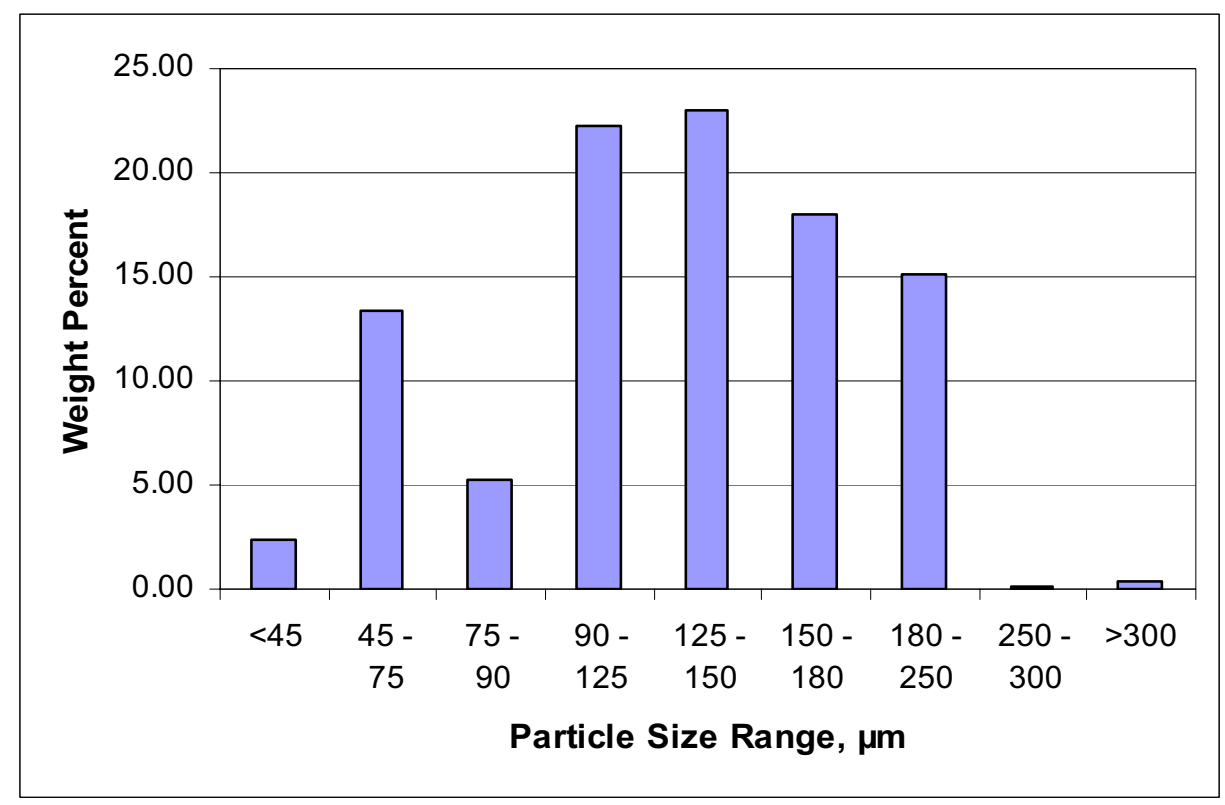

Figure 3. Zeolite particle size distribution

After being sized, the zeolite must be dried (Ref. 3). There are two motivating factors for zeolite drying. One is the effect of water on the salt/zeolite blending step in the v-mixer. The other is the effect of moisture on the waste form. The former effect is believed to be much more important, because most of the water would likely be driven 
off in the blending step, if not done so already. And the residual water left in the saltloaded zeolite after blending would likely be driven off during the pressureless consolidation step. Because the PC process takes place in an open system, moisture generated would be easily released. The threshold for how much water in the zeolite is acceptable is not easily estimated. For this reason, the approach that was taken in developing of the ceramic waste process was to dry the zeolite as much as is reasonably achievable. A limit of $1.0 \mathrm{wt} \%$ has been selected and a range of 0.1 to $0.3 \mathrm{wt} \%$ has been typically achieved.

To dry the zeolite, Kemp Development Corporation (KDC) of Houston, Texas fabricated a vacuum mechanically fluidized dryer (MFD) to drying zeolite on a relatively large scale (30-50 kg/batch). The MFD system consists of a cylindrical-shaped retort with cones on each end, which rotates inside a fixed furnace as shown in Figure 4. A photograph of the MFD is shown in Figure 5.

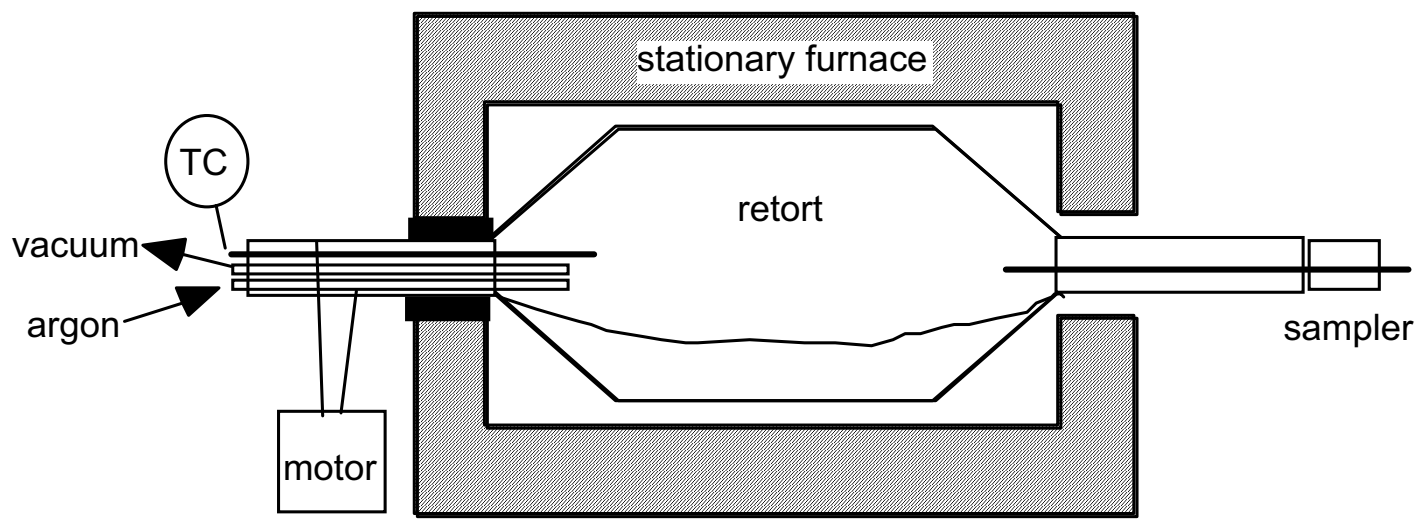

Figure 4 Schematic of mechanically fluidized dryer for zeolite

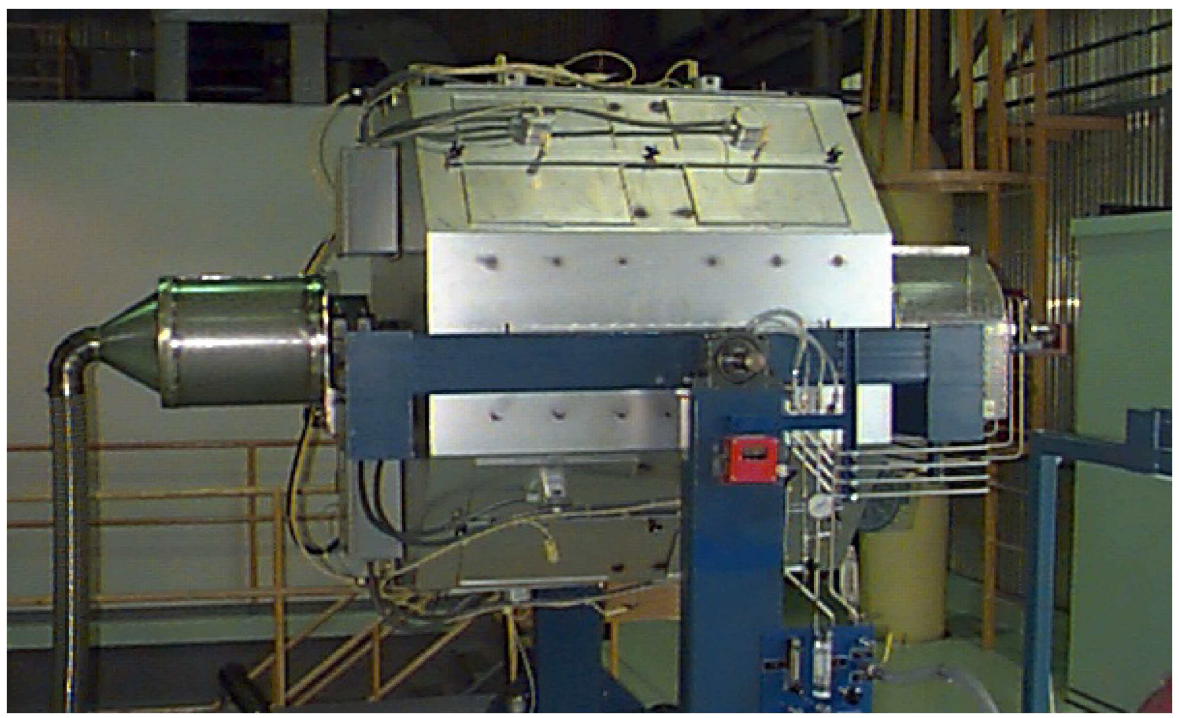

Figure 5. Photograph of the Mechanically Fluidized Dryer.

Zeolite is loaded into the MFD and the temperature is raised at $2^{\circ} \mathrm{C} / \mathrm{min}$ to $550^{\circ} \mathrm{C}$ where it is held for about one hour. During this time the MFD is vented to atmosphere to 
allow the evolved moisture to escape. The vent is then closed and the pressure is reduced to less than 100 torr for five hours. The heaters are then turned off and the system is allowed to cool to ambient temperature before being emptied.

Salt Occlusion - Because chloride does not incorporate into a glass matrix, it must first be isolated by occlusion into a zeolite matrix (Ref. 4-6). The amount of zeolite required to contain a given amount of salt is determine by the number of $\mathrm{Cl}^{-}$ions (with associated cations) that can be occluded into a unit cell of the zeolite. Tests have shown that a loading of $3.8 \mathrm{Cl}^{-}$ions/unit cell produces an acceptable final product, with free chloride generally less than $0.1 \%$. The actual weight fraction of salt to zeolite depends upon the type of salt being processed, but ranges from about 0.10 to 0.13 .

To occlude salt into the zeolite structure requires a temperature of about $500^{\circ} \mathrm{C}$, which must be held for several hours while the salt and zeolite are continuously mixed. As the salt melts it is absorbed into the zeolite forming a salt-loaded zeolite (SLZ). To accomplish this, a heated, offset V-mixer is used. Salt and zeolite are placed into the Vmixer, which has been purged with dry argon. The V-mixer is rotated at about $17 \mathrm{rpm}$. The heater controller is set at a heat-up rate of $5^{\circ} \mathrm{C} / \mathrm{min}$ with a final set point temperature of $525^{\circ} \mathrm{C}$. A photograph of the $\mathrm{V}$-mixer, which is located in a hot cell, is shown in Figure 6. It is assumed that there is no significant free liquid salt in the V-mixer. The Vmixer is maintained at this temperature for about 18 hours and is then is allowed to cool to ambient while still rotating. When the V-mixer is cooled, three samples of salt-loaded zeolite (SLZ) are withdrawn to perform free chloride analysis. The SLZ is considered acceptable if the free chloride is less than $0.5 \%$. Typically, the free chloride concentration is less than $0.1 \%$

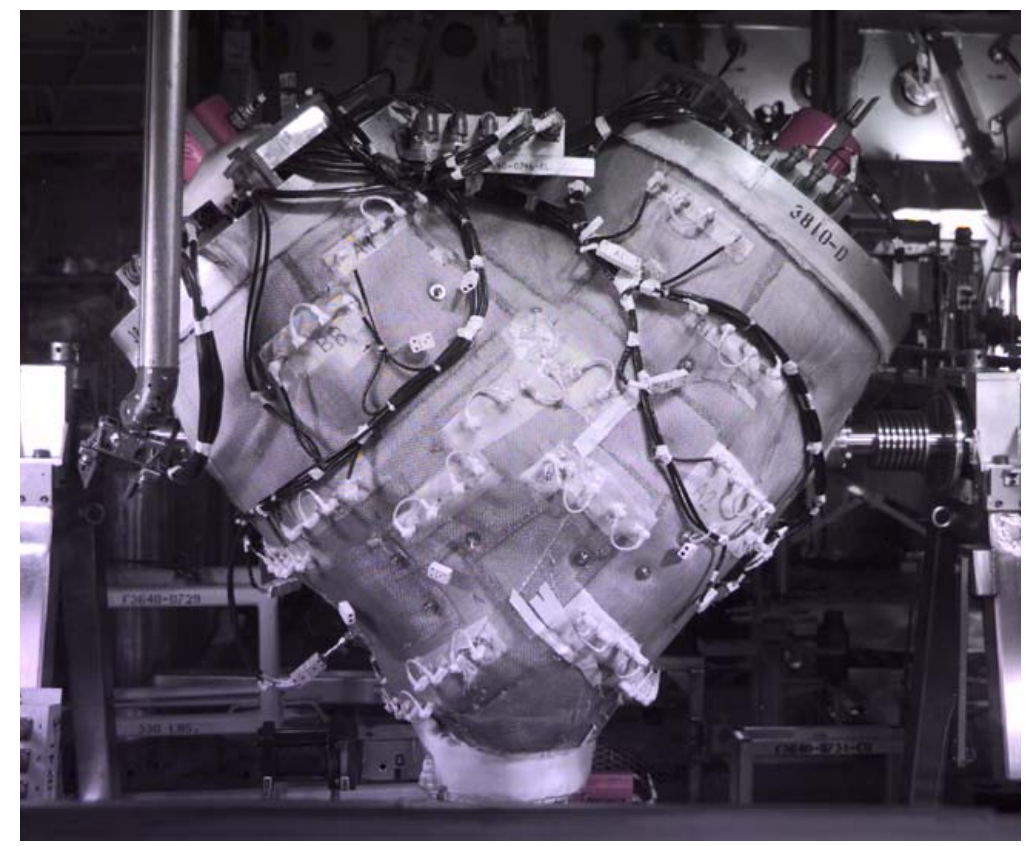

Figure 6. Heated V-mixer used to produce salt-loaded zeolite

Glass - A number of glasses of various compositions have been tested during early development. From that work, borosilicate glass was selected for the CWF process based on the following properties. 
- The glass needs to have a relatively low softening temperature $\left(<\sim 750^{\circ} \mathrm{C}\right)$.

- The glass should have a relatively broad glass working range so the glass doesn't drain through the zeolite/sodalite.

- The glass must wet the zeolite or sodalite-salt mixture.

- The coefficient of thermal expansion of the glass should match the zeolite or sodalite-salt mixture.

- The glass powder should be free flowing.

- The glass should exhibit inherently efficient packing of $\sim 40 \%$ to $45 \%$ theoretical density.

- The glass should undergo uniform densification during heating cycle

- The glass should produce a non-friable waste form surface

Until recently, the baseline borosilicate glass for the CWF was Pemco Glass 57. However, Pemco no longer produces this glass, so a substitute became necessary. A study was undertaken recently to select an alternative glass to be used in the CWF process. Several glasses from different manufacturers were obtained. These glasses are normal production runs; no attempt was made, at this time, to obtain custom compositions or particle sizes.

The compositions of these glasses are shown in Figure 7. As can be seen, the compositions are similar. The new glasses are somewhat higher in silica and somewhat lower in alumina and soda than the Pemco glass. Subsequent testing of these glasses in the CWF process showed that, while there are slight differences in performance, they all produce an acceptable CWF. As a result, a new supplier of glass will be selected in 2007.

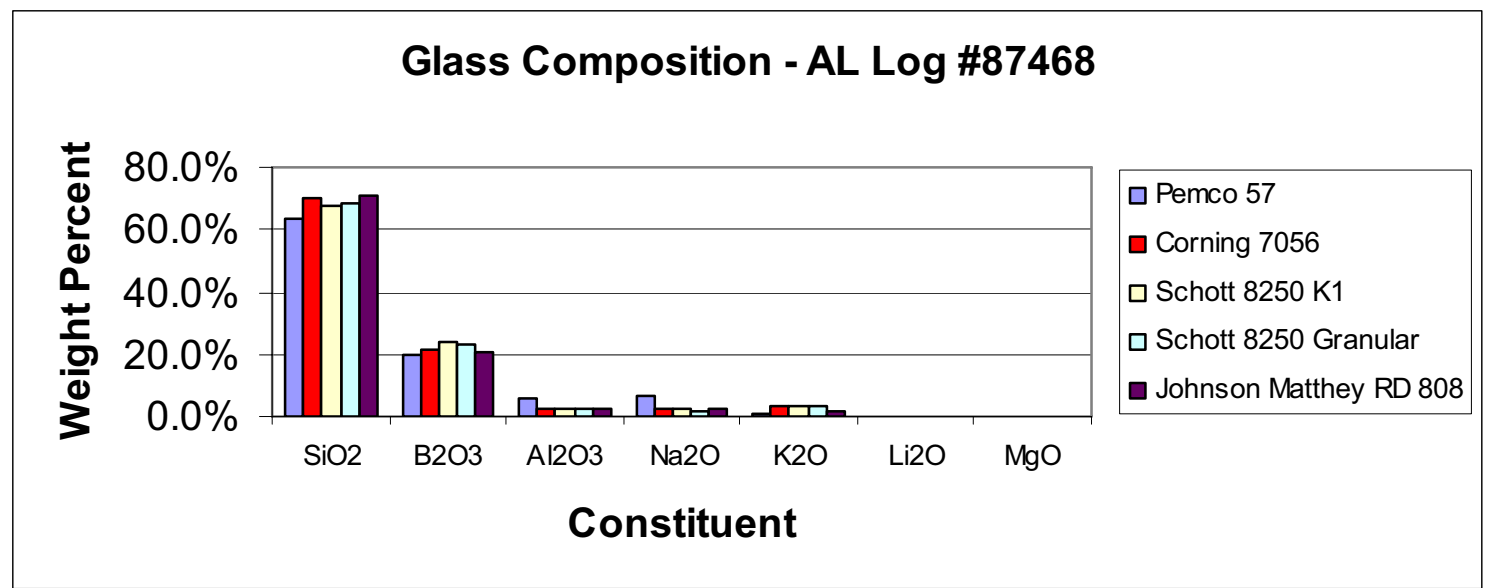

Figure 7. Composition of borosilicate glasses used in the alternative glass study, as determined by the INL MFC Analytical Laboratory.

The particle sizes of the glasses were measured and the results are shown in Figure 8. Although there are differences in the particles distributions of the various glasses, they all fall generally in the desired range of $45 \mu \mathrm{m}$ to $250 \mu \mathrm{m}$. 


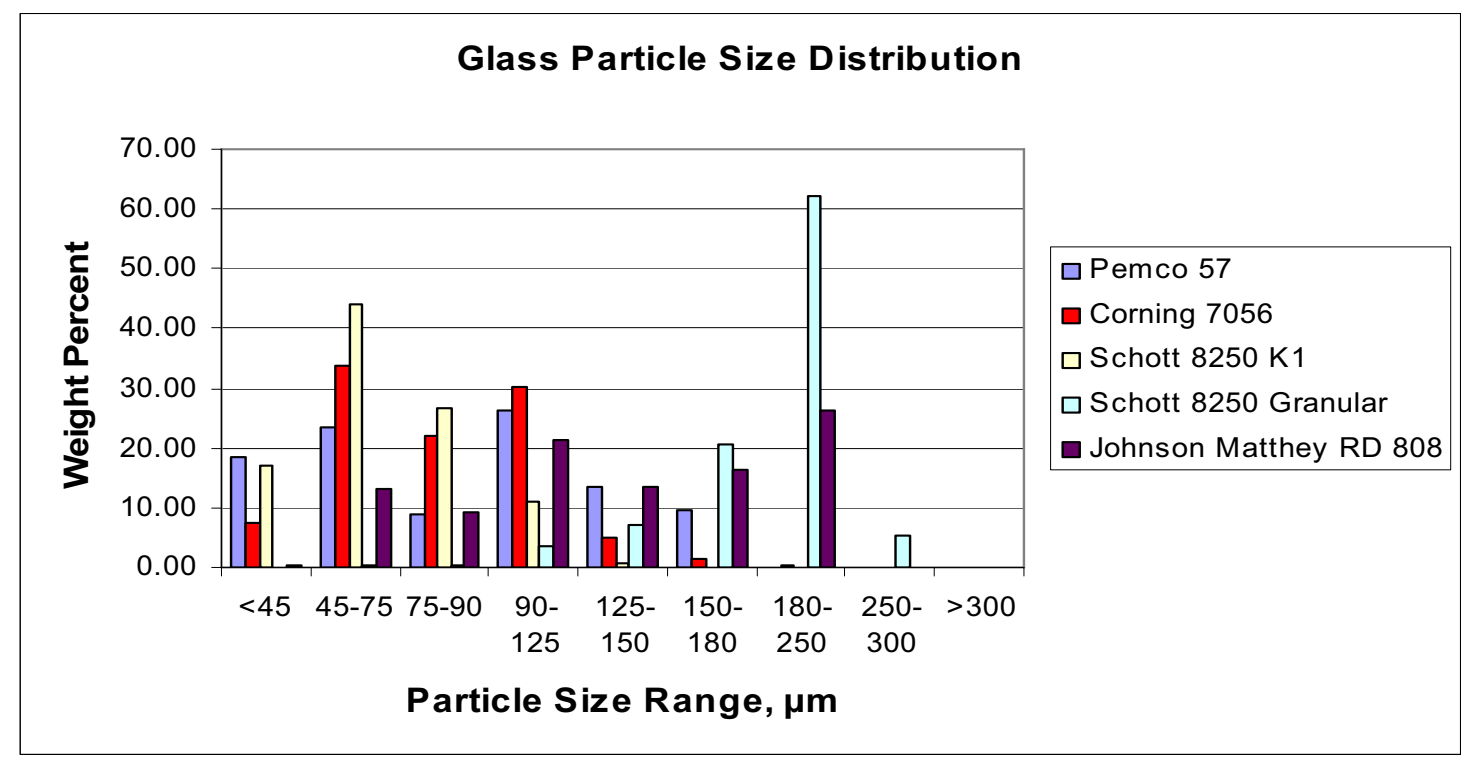

Figure 8. Particle size distribution of glasses used in alternative glass study.

Pressureless Consolidation Processing - When the free chloride has been shown to be acceptable, glass is added to the SLZ in the V-mixer and mixed at ambient temperature to produce a homogenous mixture (Ref. 7). The fraction of glass in the mixture is about $25 \%$. This mixture is then transferred to a furnace for final processing. This process is known as pressureless consolidation (PC)

The heating profiles for various sizes of CWFs are similar, but the actual times are longer for larger sizes. For small test samples $(1 \mathrm{~kg})$ the furnace temperature is raised at $10^{\circ} \mathrm{C} / \mathrm{min}$ to $500^{\circ} \mathrm{C}$ where it is held for about two hours. It is then raised to $925^{\circ} \mathrm{C}$ for the final 15 hours. $140 \mathrm{~kg}$ specimens were made by holding the furnace at $925^{\circ} \mathrm{C}$ for 100 hours. The production-scale furnace will produce up to a $400 \mathrm{~kg} \mathrm{CWF}$, but it will be the same diameter as the $140 \mathrm{~kg}$ CWF. Because the furnace is radially heated, the heating times are expected to be relatively independent of the length of the CWF. Therefore, the cycle times should be similar. The principal difference will be cool down time. The $140 \mathrm{~kg} \mathrm{CWF}$ had no external cooling, whereas the production-scale furnace has the capability for forced argon cooling. The impact of forced cooling on process time will be investigated. The production-scale furnace has internal dimensions of $263 / 4$ inches in diameter by 123 inches high. A photo of the production-scale furnace is shown in Figure 9. This furnace was made operational in 2006 and will used for demonstration tests using surrogate material before it is installed in HFEF where it will be used to process EBR-II salt. 


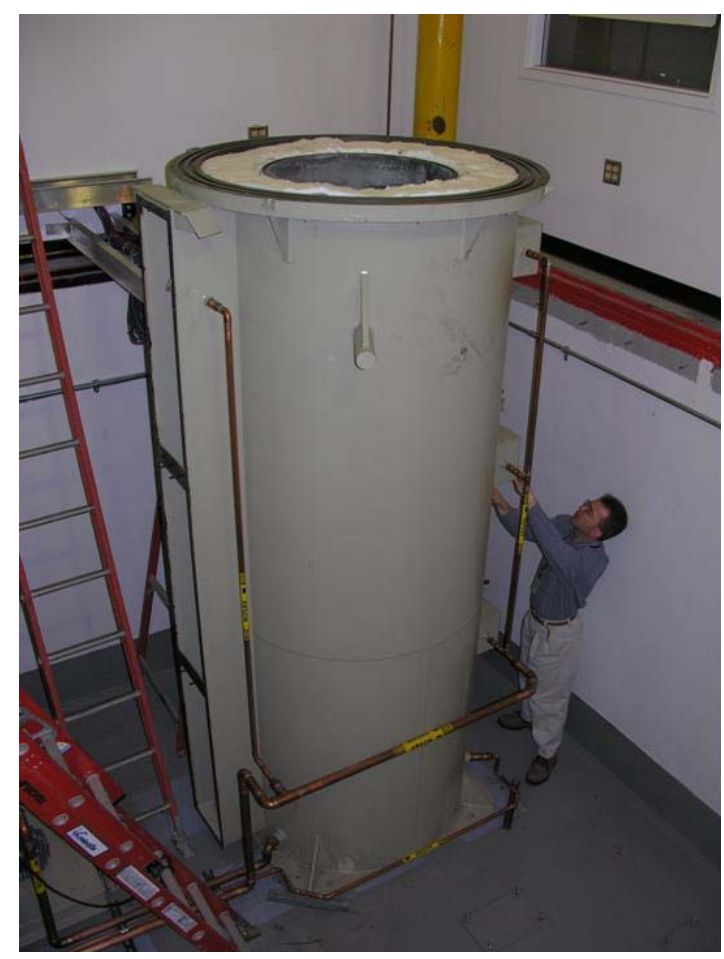

Figure 9. Production-scale CWF furnace.

Thermal Modeling of the CWF Process - The PC process has been modeled to better understand the heating and cooling requirements for the full-scale furnace (Ref. 8). This modeling has accounted not only for the heat transfer to the CWF monolith from the furnace, but also the internal heat generated by:

1. radioactive decay of fission products within the salt,

2. conversion of zeolite to sodalite, and

3. material shrinkage.

The model has been verified against experimental data using surrogate salt for $10 \mathrm{~kg}, 25 \mathrm{~kg}, 85 \mathrm{~kg}$, and $140 \mathrm{~kg}$ waste forms. The temperature and density data from the $140 \mathrm{~kg}$ CWF experiment are plotted with the predictions for the model in Figures 9 and 10 respectively. The furnace temperature was raised to $50^{\circ} \mathrm{C}$ and held for about 100 hours. The temperature was then slowly increased to $916^{\circ} \mathrm{C}$ over the next 60 hours and held there for an additional 60 hours. As is shown in Figure 9 the model accurately predicts the centerline temperature of the CWF. This is particularly important for the steep rise in temperature, because this was where the material properties changed significantly. For example, the thermal conductivity changed over an order of magnitude during this time. Additionally, the model was able to represent the exothermic reaction of what is believed to be the zeolite converting to sodalite.

The model also accurately tracked the rapid densification as the bulk temperature approached $567^{\circ} \mathrm{C}$ as shown at about 150 hours in Figure 10. The model continues to track the experiment during $915^{\circ} \mathrm{C}$ hold. The model also appeared to predict the thermal contraction of the material as it cooled at around 80 hours. The model predicted a final 
density of $1.85 \mathrm{~g} / \mathrm{cm}^{3}$, whereas the experiment yielded a final density of $1.87+/-$ $0.02 \mathrm{~g} / \mathrm{cm}^{3}$.

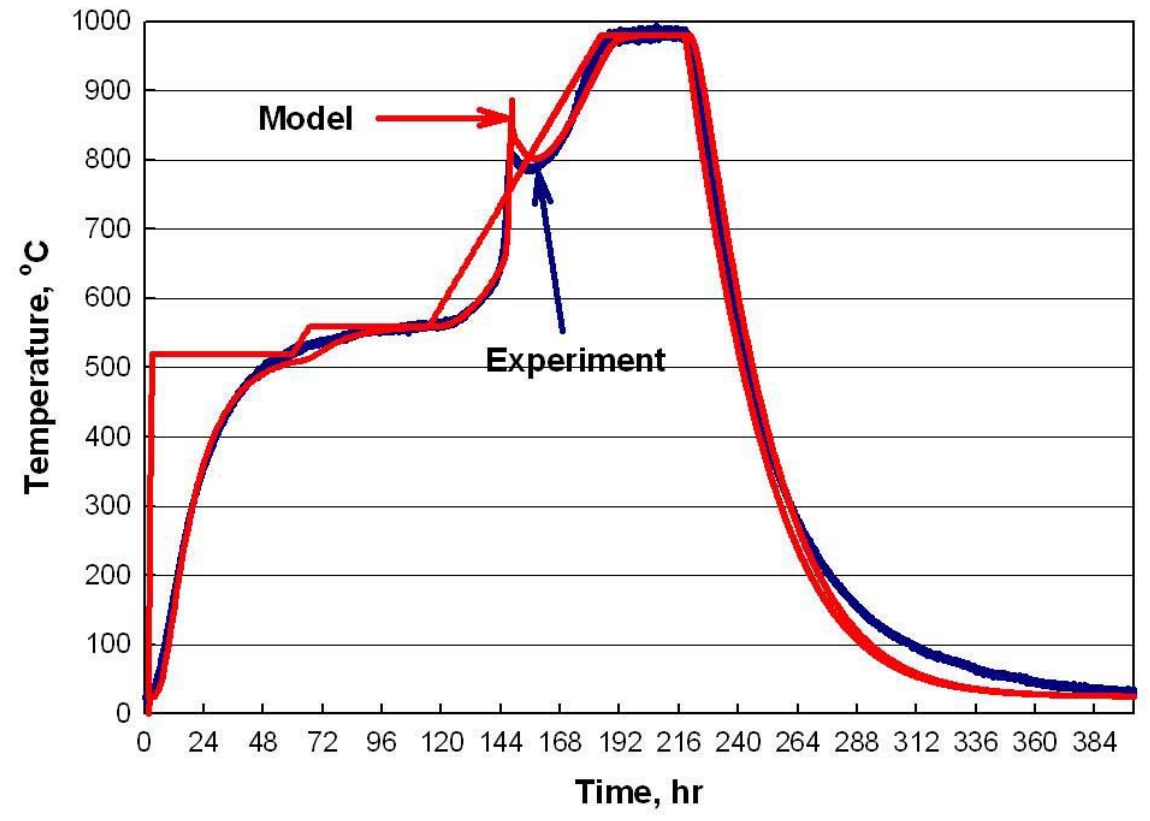

Figure 10. Comparison of model versus $140 \mathrm{~kg}$ experimental temperature data.

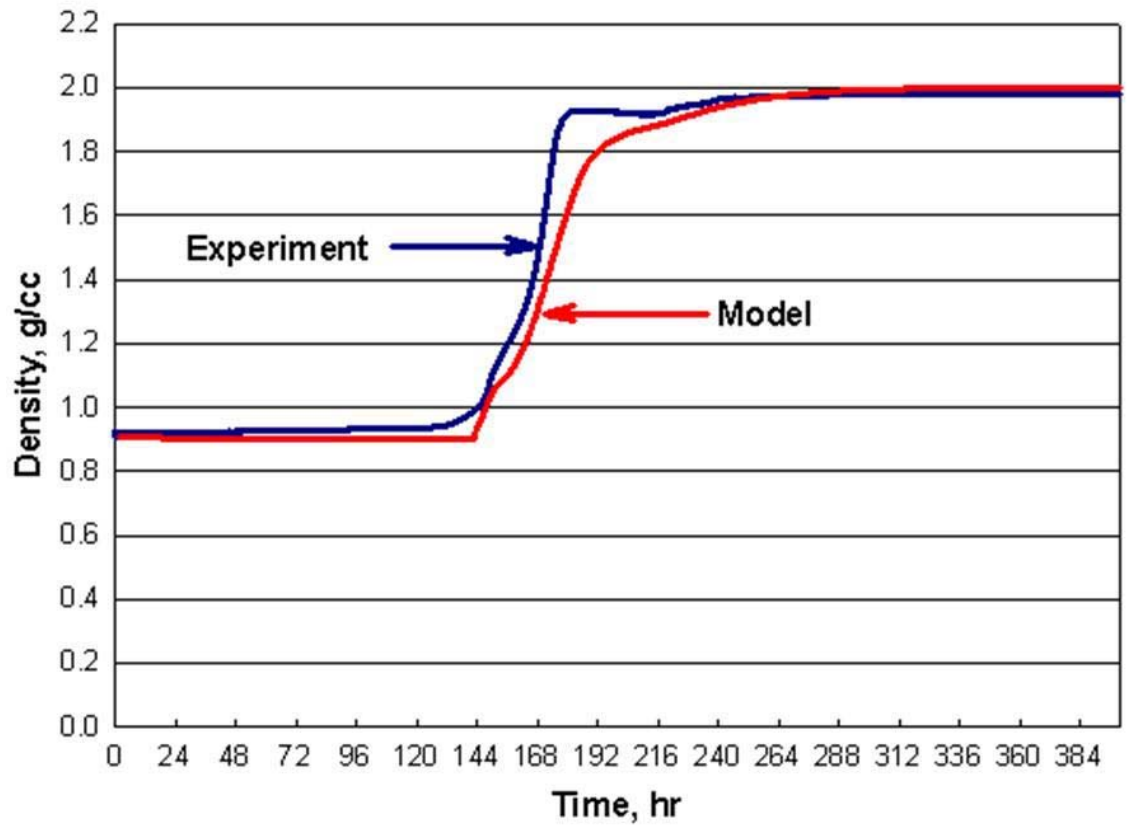

Figure 11. Comparison of experimental data with model results for $140 \mathrm{~kg} \mathrm{CWF}$. 


\section{CWF Product Quality}

The quality of CWFs is established by visual observation, density, product consistency test, X-ray diffraction, and scanning electron microscope (Ref. 9). Presented below are representative results of the most recent tests from a study of alternative glasses.

\section{Visual Observation}

CWFs are broken apart and examined visually for homogeneity and the presence of anomalies. Figure 13 is photograph of a typical CWF, which shows a uniform consistency with small inclusions and little porosity.

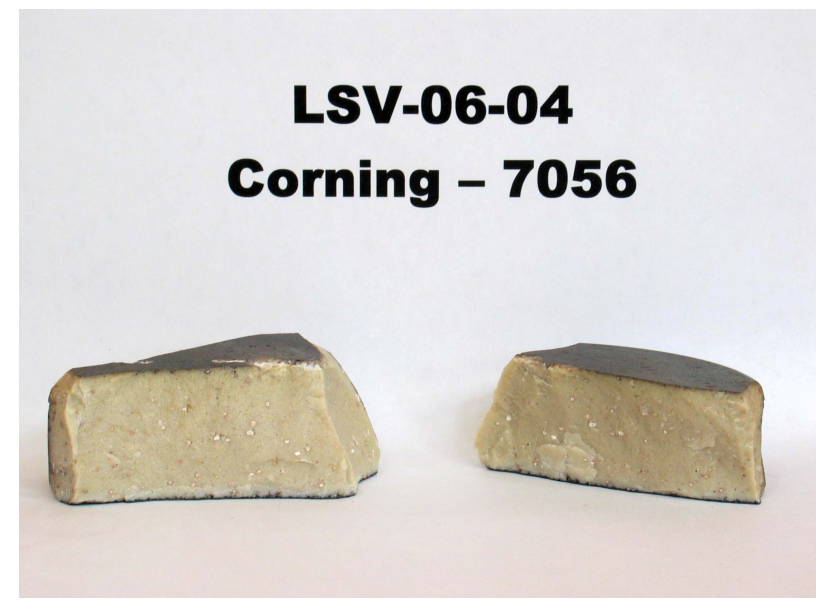

Figure 12. Photograph of CWF showing a fairly homogenous matrix with only minor inclusions, which may be unconverted zeolite.

\section{Density}

Density of the CWF is measured using helium pycnometry. The results typically range from $2.3 \mathrm{~g} / \mathrm{cc}$ to $2.4 \mathrm{~g} / \mathrm{cc}$.

\section{X-ray Diffraction (XRD)}

Samples from each CWF are ground into a fine powder and sieved through a 75 $\mu \mathrm{m}$ screen and analyzed as a thin film using XRD. The observed mineral phases are normally sodalite and halite. The ratio of sodalite to halite ranges from about 0.6 to 1.5. The differences in ratio of sodalite to halite may be due to differences in the composition of the glasses, which may impact the dissolution of sodalite into the glass, and the ion exchange mechanism when converting zeolite to sodalite. It does not impact the product durability, but may be examined more fully in the future.

\section{Chemical Durabilty}

Chemical durability of the CWFs is determined using the standard product consistency test (PCT). The test involves grinding, sizing (roughly $75 \mu \mathrm{m}$ diameter) and cleaning sample material, then placing the material in demineralized water for 7 days at $90^{\circ} \mathrm{C}$. The water leachate solution is then filtered to remove any solid material and 
analyzed for leached constituents of the waste form. The results from these tests are expressed as normalized mass loss of each elemental constituent. These values are shown in Table 4 and are compared with the normalized mass loss from the reference CWF. Release rates of the all the matrix elements ( $\mathrm{Si}, \mathrm{Al}, \mathrm{B}$, and $\mathrm{K}$ ) are at least an order of magnitude lower than a comparable EA glass. The salt components ( $\mathrm{Li}, \mathrm{Na}$, and $\mathrm{Cl}$ ) are not measured for EA glass.

Table 4. PCT analysis results for CWF showing normalized mass loss

\begin{tabular}{|c|c|c|c|c|c|c|c|}
\hline & \multicolumn{3}{|c|}{ Matrix Elements } & \multicolumn{3}{c|}{ Salt Elements } \\
\hline Element & $\mathrm{Si}$ & $\mathrm{Al}$ & $\mathrm{B}$ & $\mathrm{K}$ & $\mathrm{Li}$ & $\mathrm{Na}$ & $\mathrm{Cl}$ \\
\hline $\begin{array}{c}\text { Normalized } \\
\text { Mass Loss }\end{array}$ & 0.047 & 0.045 & 0.138 & 0.226 & 0.59 & 0.39 & 2.04 \\
\hline
\end{tabular}

\section{Scanning Electron Microscopy (SEM)}

The micro-structural composition of the CWF is determined by SEM in both secondary electorn (SE) and back scattered electron (BSE) modes. Figures 13 shows a representative pair of SE and BSE micrographs at 200X and 1000X magnification.

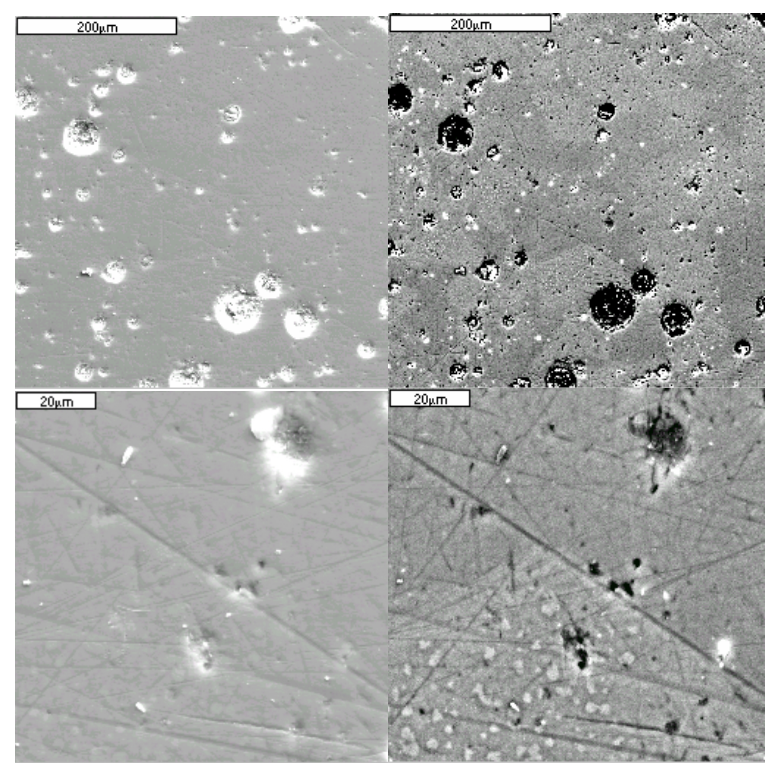

Figure 13. Micrograph of CWF. 200X magnification is shown on the top. SE images are shown on the left and BSE images are shown on the right.

Elemental compositions of the two primary phases, sodalite and glass, are also determined by acquiring energy dispersive spectroscopy (EDS) spectra from ten points in each phase. These spectra were then analyzed and the results from each group of ten points averaged. Recent results are shown in Figure 16. 


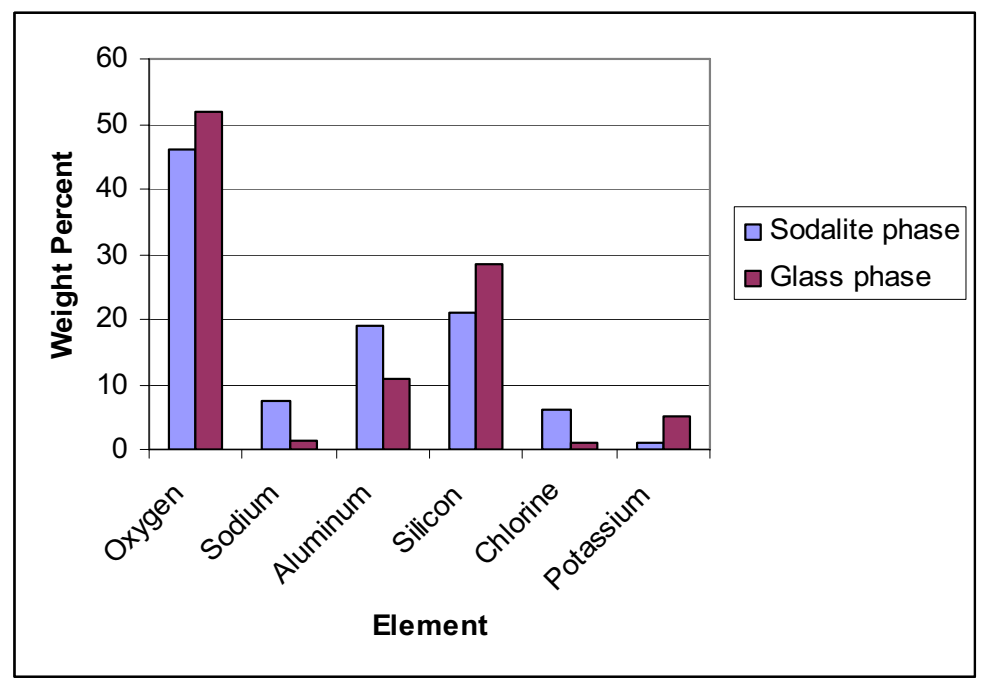

Figure 16. Elemental analysis of sodalite and glass phases in CWFs

\section{Material Handling and Transfer}

Production of the ceramic waste form (CWF) involves three powder materials, electrorefiner salt, zeolite 4A, and borosilicate glass. Each of these materials is processed or purchased to produce a particle size range of $45 \mu \mathrm{m}$ to $250 \mu \mathrm{m}$. Powder flow characteristics are important in that material must be transferred from one unit operation to the next in a process. Conditions such as bridging, rat-holing, arching, and agglomeration can be very problematic. In terms of the CWF process, there are several operations that require handling powders:

- Transfer canisters will be used to move materials between equipment items. These canisters are typically a cylindrical container (such as a drum) with a conical head through which the material will flow.

- Zeolite will be received from the vendor in drums and must be transferred to a grinder. This as-received zeolite flows very well and is not deemed to be a concern. However, once ground, the material exhibits bridging and rat-holing problems. This material is placed into transfer canisters and is then transferred to the MFD.

- $\quad$ Salt and zeolite are transferred to the V-mixer. After salt occlusion, glass frit powder is added to the $\mathrm{V}$-mixer. The SLZ-glass mixture is then emptied from the $\mathrm{V}$-mixer back into a transfer canister.

- Finally, the SLZ/glass mixture is transferred to the furnace.

To better understand the flow properties of the various CWF materials, samples of salt, zeolite, SLZ, glass, and SLZ-glass mixture were prepared and sent to Diamondback Technologies (Ref. 10) who measured a set of material flow indices. These indices, known as Johanson indices, measure the tendency of a powder material to bridge, arch, and rat-hole in storage bins, hoppers, and chutes. The measured indices are shown in Table 1. Diamondback Technologies also assessed existing CWF process equipment as 
to whether there would be problems with material flow. They also made recommendations about potential design changes that might improve material flow.

Table 1. Summarized Johanson Flow Indices

\begin{tabular}{|c|c|c|c|c|c|}
\hline Index & Units & Zeolite 4A & $\begin{array}{l}\text { Salt Loaded } \\
\text { Zeolite }\end{array}$ & $\begin{array}{c}\text { Eutectic } \\
\text { Salt }\end{array}$ & $\begin{array}{c}\text { Borosilicate } \\
\text { Glass }\end{array}$ \\
\hline \multicolumn{6}{|c|}{ Flow Rate Indices } \\
\hline Flow Rate Index & $\mathrm{Lb} / \mathrm{Min}$ & 3.2 & 8.0 & 15.4 & 32.4 \\
\hline Feed Density Index & $\mathrm{Lb} / \mathrm{Ft}^{3}$ & 37.7 & 46.6 & 46.7 & 71.1 \\
\hline Bin Density Index & $\mathrm{Lb} / \mathrm{Ft}^{3}$ & 45.3 & 50.9 & 55.6 & 75.1 \\
\hline \multicolumn{6}{|c|}{$\begin{array}{c}\text { Hangup Indices } \\
\text { 0 hours }\end{array}$} \\
\hline Arching Index & $\mathrm{ft}$ & 0.6 & 0.2 & 0.4 & 0.2 \\
\hline Rat-holing Index & $\mathrm{ft}$ & 1.4 & 0.5 & 0.9 & 0.3 \\
\hline \multicolumn{6}{|c|}{2 hours } \\
\hline Arching Index & $\mathrm{ft}$ & 0.8 & 0.3 & 1.0 & 0.2 \\
\hline Rat-holing Index & $\mathrm{ft}$ & 2.5 & 0.6 & 2.4 & 0.3 \\
\hline \multicolumn{6}{|c|}{ 304-\#1 stainless steel } \\
\hline Hopper Index & degree & 13 & 13 & 10 & 13 \\
\hline
\end{tabular}

FRI - Flow rate index - The FRI indicates the maximum flow rate of material through a specified diameter opening.

FDI - Feed density index - The FDI measures the density of the material while it is being fed from a bin or hopper

BDI - Bin density index - The BDI measures the density of the material as it is stagnant in the bin or hopper. When combined with the FDI, the BDI gives an indication of the compressibility of a material.

AI - Arching index - The AI provides the minimum diameter of bin opening that will prevent arching of material across the opening. It is measured at time zero, and then at a time representative of the time that material is expected to remain in a bin before it emptied. This is difficult to predict for the CWF process, but was taken to be two hours.

RI - Rat-hole index - Similar to the AI, the RI provides the minimum diameter of bin opening that will prevent rat-holing. Again, the AI is taken instantaneously and after two hours.

HI - Hopper index - The HI measures the minimum angle of a hopper opening that will permit material to flow. It is measured from vertical, so the smaller the HI, the steeper hopper angle will be required. The HI is a function of hopper material, so it is measured with a variety of materials.

The following observations and recommendations have been made for each of the materials of interest.

Salt - Based on the flow indices, the salt will have a propensity for arching and rat-holing in the crrent transfer can. In addition, the angle of the conical discharge head may be too low to allow complete discharge.

Zeolite - Zeolite was found to be the most problematic material. It will rapidly arch or rat-hole when emptying both the transfer can and the MFD. The angles of the conical portions of both the transfer can and the MFD may be insufficient. This problem 
has been observed during the limited amount of MFD runs. Currently, the MFD is emptied by tilting and rotating, which is awkward at best. Completely emptying the MFD has been a problem.

Glass - The glass is the least problematic of the materials. It flows well in current equipment. Therefore, no changes are needed.

SLZ/glass mixture - As with the salt and zeolite individually, the SLZ/glass mixture will likely arch and rat-hole in the current transfer can. The angle of the " $\mathrm{V}$ " in the V-mixer is sufficient to promote material flow, but the diameter of the current fill/discharge opening may be too small to prevent arching or rat-holing.

Recommendations are currently being developed regarding potential modifications to the transfer cans, the MFD and the V-mixer. As appropriate, these will be incorporated into the production-scale process.

\section{Summary}

The process of occluding salt into a zeolite matrix and then converting that matrix to a sodalite form and encapsulating it in glass has been shown to be a robust method for isolating the salt byproduct from electrochemical treatment of spent EBR II fuel. The process has been demonstrated on surrogate materials up to near-production scale and on radioactive material on limited quantities. INL is working to complete and test a production-scale process and will then move on to treatment of remaining electrorefiner salt.

\section{References}

1. Goff, K.M., R.W. Benedict, K.J. Bateman, M.A. Lewis, C. Pereira, and C.A. Musick, "Spent Fuel Treatment and Mineral Waste Form Development at Argonne National Laboratory-West," International Topical Meeting on Nuclear and Hazardous Waste Management, American Nuclear Society, 3:2436, Seattle, WA, August 18-23, 1996.

2. Simpson, M.F., K.M. Goff, S.G. Johnson, K.J. Bateman, T.J. Battisti, K.L. Toews, S.M. Frank, T.L. Moschetti, and T.P. O'Holleran, “A Description of the Ceramic Waste Form Production Process From the Demonstration Phase of the Electrometallurgical Treatment of EBR-II Spent Fuel," Nuclear Technology, v134, 263-277, June 2001.

3. Simpson, M.F. and T.J. Battisti, "Adsorption of Eutectic LiCl-KCl into Zeolite 4A Using a Mechanically Fluidized Vacuum System,” Ind. Eng. Chem. Res., 38 (1999), 2469-2473.

4. Lewis, M.A., D.F. Fischer, and L.J. Smith, "Salt-Occluded Zeolites as an Immobilization Matrix for Chloride Waste Salt," J. Am. Ceram. Soc., 76(11), 2826-2832, 1993.

5. Pereira, C., V.N. Zyryanov, M.A. Lewis, and J.P. Ackerman, "Mixing of Zeolite Powders and Molten Salt," Ceramic Transactions (Environmental Issues and Waste Management Technologies in the Ceramic and Nuclear Industries II), 72(1996), 485-494. 
6. Simpson, M.F., S. Lance, and G. Moore; "Kinetics of Molten Chloride Salt Sorption into Zeolite-4A," Light Metals 2002: Proceedings of the TMS Annual Meeting (February 2002).

7. T.J. Battisti, K.M. Goff, K. J. Bateman, M.F. Simpson, and J.P. Lind, "Ceramic Waste Form Production and Development at ANL-West," Proceedings of 5th Topical DOE Spent Nuclear Fuel and Fissile Materials Management, Charleston, SC September 17-20, 2002.

8. Bateman, K.J. and D.D. Capson, "Consolidating Electrorefined Spent Nuclear Fuel Waste - Analysis and Experiment," Proceedings of ASME International Mechanical Engineering Congress and Exposition, IMECE2003-41806, Washington, DC, November 16-21, 2003.

9. Johnson, S.G., S.M. Frank, T. P. O'Holleran, M.H. Noy, T. DiSanto, K.M. Goff, K.J. Bateman, "Characterization and Durability Testing of a Glass-Bonded Ceramic Waste Form," Ceram. Trans., Vol. 93, pp 313-320, 1999.

10. Dudley, L. and K. O'Quest, "Flow Properties of Ceramic Waste Form Process Samples," May 8, 2006. 